\title{
Edoksaban - kolejny NOAC w armamentarium leków przeciwkrzepliwych; czym różni się od pozostałych? Wyniki badań klinicznych z zastosowaniem edoksabanu
}

\author{
Edoksaban - another NOAC in the armamentarium of anticoagulants \\ - how it differs from the others? The results of clinical trials of edoxaban
}

\author{
Olga Jelonek ${ }^{1}$, Iwona Gorczyca-Michta ${ }^{1}$, Beata Wożakowska-Kapłon ${ }^{1,2}$ \\ ${ }^{1}$ I Klinika Kardiologii i Elektroterapii Świętokrzyskiego Centrum Kardiologii w Kielcach \\ ${ }^{2}$ Wydział Lekarski i Nauk o Zdrowiu Uniwersytetu Jana Kochanowskiego w Kielcach
}

\section{Streszczenie}

Doustne antykoagulanty niebędące antagonistami witaminy K (NOAC) wykazały skuteczność i bezpieczeństwo w wielu badaniach klinicznych. Leki te stanowią obiecującą alternatywę dla standardowej terapii przeciwkrzepliwej. Jednym z nich jest edoksaban - wysoce wybiórczy, odwracalny i bezpośredni inhibitor czynnika Xa. Znalazł zastosowanie w stanach wymagających profilaktyki i leczenia przeciwkrzepliwego, takich jak zapobieganie udarom mózgu i zatorowości systemowej u pacjentów z niezastawkowym migotaniem przedsionków oraz leczenie zakrzepicy żył głębokich i zatorowości płucnej. Niniejszy artykuł zawiera analizę badań klinicznych przeprowadzonych w celu oceny bezpieczeństwa i skuteczności stosowania edoksabanu.

Słowa kluczowe: doustne antykoagulanty niebędące antagonistami witaminy K, edoksaban, warfaryna, migotanie przedsionków, żylna choroba zakrzepowo-zatorowa

Folia Cardiologica 2017; 12, 1: 61-67

\section{Wstęp}

Doustne antykoagulanty niebędące antagonistami witaminy $\mathrm{K}$ (NOAC, non-vitamin K antagonist oral anticoagulants) w selektywny sposób hamują swoiste inhibitory czynników krzepnięcia. Obecnie dostępne są następujące leki z tej grupy: dabigatran, będący bezpośrednim inhibitorem trombiny, oraz rywaroksaban, apiksaban i edoksaban, które są bezpośrednimi inhibitorami czynnika Xa. W przeciwieństwie do standardowej terapii przeciwkrzepliwej prowadzonej przy użyciu antagonistów witaminy K (VKA, vitamin K antagonists), jak warfaryna czy acenokumarol, leczenie NOAC nie wymaga monitorowania parametrów krzepnięcia krwi podczas ich stosowania, zachowuje się przy tym korzystny profil bezpieczeństwa i wysoką skuteczność.

Edoksaban jest doustnym, wysoce wybiórczym, odwracalnym i bezpośrednim inhibitorem czynnika Xa - proteazy serynowej występującej na końcu wewnętrznych i zewnętrznych dróg krzepnięcia. Hamowanie aktywności tego czynnika prowadzi do zmniejszenia ilości powstającej trombiny, wydłużenia czasu krzepnięcia, co skutkuje zmniejszeniem ryzyka powstawania zakrzepów. Edoksaban wykazuje 62-procentową biodostępność po podaniu doustnym. Lek osiąga maksymalne stężenie w osoczu w ciągu 1-2 h od

Adres do korespondencji: lek. Olga Jelonek, I Klinika Kardiologii i Elektroterapii, Świętokrzyskie Centrum Kardiologii, ul. Grunwaldzka 45, 25-736 Kielce, tel. 413671 510, faks 413671 396; e-mail: olga_jelonek@wp.pl 
podania, średni okres półtrwania zaś wynosi 8-10 h. Lek w osoczu występuje głównie w postaci niezmienionej. Metabolizowany jest przez hydrolizę, sprzęganie lub utlenianie do trzech aktywnych metabolitów. Eliminacja edoksabanu zachodzi głównie przez nerki (11 l/h). U pacjentów z niewydolnością nerek oraz u osób z niską masą ciała ( $\leq 60 \mathrm{~kg})$ konieczna jest modyfikacja dawek leku [1].

Edoksaban jest także substratem dla transportera glikoproteiny $\mathrm{P}$ (P-gp), znajdującego się głównie w jelicie cienkim, odpowiedzialnego za zwrotny transport leków do światła jelita, co ogranicza ich systemową absorpcję. W razie jednoczesnego stosowania leków będących silnymi inhibitorami glikoproteiny $P$, takich jak chinidyna, werapamil czy dronedaron, dawki edoksabanu muszą być zmniejszone [1, 2].

\section{Edoksaban w prewencji udaru i zatorowości systemowej w niezastawkowym migotaniu przedsionków}

W celu oceny długoterminowej skuteczności i bezpieczeństwa edoksabanu w profilaktyce udaru i zatorowości systemowej w grupie pacjentów z niezastawkowym migotaniem przedsionków (NVAF, nonvalvular atrial fibrillation) i umiarkowanym lub wysokim ryzykiem incydentów zakrzepowo-zatorowych w porównaniu z warfaryną przeprowadzono badanie ENGAGE AF-TIMI 48 (The Effective Anticoagulation with Factor Xa Next Generation in Atrial Fibrillation-Thrombolysis in Myocardial Infarction 48). Było to wieloośrodkowe, randomizowane badanie kliniczne 3 fazy z podwójnie ślepą próbą, w którym wzięło udział 21105 pacjentów z wynikiem w skali $\mathrm{CHADS}_{2}$ wynoszącym co najmniej 2 punkty [1]. W badaniu oceniano profil bezpieczeństwa i skuteczności 2 dawek edoksabanu (30 i 60 mg podawanych raz/dobę) w porównaniu z warfaryną.
W przypadku wystąpienia jednego lub więcej spośród następujących czynników: niska masa ciała ( $\leq 60 \mathrm{~kg}$ ), umiarkowana lub ciężka niewydolność nerek (klirens kreatyniny 30-50 ml/min) lub jednoczesne przyjmowanie inhibitorów glikoproteiny $\mathrm{P}$, w obydwu grupach przyjmujacych edoksaban dawka leku była zmniejszona o połowe: do $15 \mathrm{mg}$ lub $30 \mathrm{mg}$ raz/dobę [1, 3]. Pierwszorzędowy punkt końcowy w badaniu stanowiło wystąpienie udaru (niedokrwiennego lub krwotocznego) lub zatorowości systemowej. Za drugorzędowy punkt końcowy przyjęto wystąpienie udaru, zatorowości systemowej lub śmierci z przyczyn sercowo-naczyniowych. W zakresie bezpieczeństwa terapii za najważniejszy punkt końcowy uznano wystąpienie poważnego krwawienia [3]. Mediana czasu trwania ekspozycji na lek w badaniu dla obydwu dawek edoksabanu wynosiła 2,5 roku, natomiast mediana czasu obserwacji pacjentów - 2,8 roku. W grupie pacjentów otrzymujących warfarynę mediana czasu, w którym stężenie leku znajdowało się w przedziale wartości terapeutycznych (międzynarodowy współczynnik znormalizowany [INR, international normalized ratio] 2,0-3,0) wynosiła $68,4 \%$ [3]. W tabeli 1 przedstawiono roczny odsetek występowania punktów końcowych w badaniu.

W trakcie aktywnego leczenia w grupie leczonej warfaryną oraz w grupach leczonych edoksabanem podawanym w dawkach 60 mg i 30 mg wystąpiły, odpowiednio, 232, 182 i 253 incydenty udaru lub zatorowości systemowej. Liczba poważnych krwawień, krwawień wewnątrzczaszkowych, a także krwawień zagrażających życiu była istotnie niższa w grupach leczonych edoksabanem w porównaniu z przyjmującymi warfarynę, z wyjątkiem krwawienia z przewodu pokarmowego, które pojawiało się częściej w grupie przyjmującej edoksaban w dawce $60 \mathrm{mg}$, rzadziej w przypadku dawki 30 mg w porównaniu z warfaryną. Natomiast nie stwierdzono istotnych różnic w zakresie częstości

Tabela 1. Występowanie punktów końcowych w badaniu ENGAGE AF-TIMI 48 (The Effective Anticoagulation with Factor Xa Next Generation in Atrial Fibrillation-Thrombolysis in Myocardial Infarction 48) w ciągu roku (źródło [3])

\begin{tabular}{|c|c|c|c|c|c|}
\hline Punkty końcowe & Warfaryna & $\begin{array}{l}\text { Edoksaban } \\
60 \mathrm{mg}\end{array}$ & $\begin{array}{c}p \\
\text { edoksaban } 60 \mathrm{mg} \\
\text { v. warfaryna }\end{array}$ & $\begin{array}{l}\text { Edoksaban } \\
30 \mathrm{mg}\end{array}$ & $\begin{array}{c}p \\
\text { edoksaban } 30 \mathrm{mg} \\
\text { v. warfaryna }\end{array}$ \\
\hline $\begin{array}{l}\text { Pierwszorzędowy punkt końcowy (udar } \\
\text { niedokrwienny, udar krwotoczny, zatoro- } \\
\text { wość systemowa) }\end{array}$ & 1,50 & 1,18 & $<0,001$ & 1,61 & 0,005 \\
\hline Udar krwotoczny & 0,47 & 0,26 & $<0,001$ & 0,16 & $<0,001$ \\
\hline Udar niedokrwienny & 1,25 & 1,25 & 0,97 & 1,77 & $<0,001$ \\
\hline $\begin{array}{l}\text { Drugorzędowy punkt końcowy (udar, za- } \\
\text { torowość systemowa, zgony z przyczyn } \\
\text { sercowo-naczyniowych) }\end{array}$ & 4,43 & 3,85 & 0,005 & 4,23 & 0,32 \\
\hline Zgony z przyczyn sercowo-naczyniowych & 3,17 & 2,74 & 0,013 & 2,71 & 0,008 \\
\hline Poważne krwawienia & 3,43 & 2,75 & $<0,001$ & 1,61 & $<0,001$ \\
\hline
\end{tabular}


zgonów z przyczyn sercowo-naczyniowych i zgonów z jakiejkolwiek przyczyny w obu grupach leczonych edoksabanem w porównaniu z grupą przyjmującą warfarynę, w której roczne odsetki tych zdarzeń wynosiły, odpowiednio, 3,17\% i 4,35\%. W analizie zgodnej z zaplanowanym leczeniem zaobserwowano trend w kierunku większej skuteczności edoksabanu w większej dawce (hazard względny [HR, hazard ratio] 0,87; 97,5-proc. przedział ufności [Cl, confidence interval] 0,73-1,04; $p=0,08$ ) i trend w kierunku mniejszej skuteczności edoksabanu w mniejszej dawce (HR 1,13; 97,5\% Cl 0,96-1,34; $p=0,10$ ) w porównaniu z warfaryną [3].

W badaniu ENGAGE AF-TIMI 48 oceniono także skuteczność i bezpieczeństwo edoksabanu w porównaniu z warfaryną u pacjentów, którzy wcześniej stosowali bądź nie stosowali VKA. W wynikach wykazano, że większe dawki edoksabanu znacząco redukowały ryzyko wystąpienia udaru lub zatorowości systemowej w porównaniu z warfaryną u pacjentów nieprzyjmujących uprzednio VKA (HR 0,71, 95\% $\mathrm{Cl} \mathrm{0,56-0,90),} \mathrm{natomiast} \mathrm{wśród} \mathrm{badanych} \mathrm{stosujących}$ wcześniej taką terapię roczny odsetek tych zdarzeń był zbliżony (HR 1,01, 95\% Cl 0,82-1,24; $p=0,028$ ). W prewencji udaru i zatorowości systemowej mniejsze dawki edoksabanu cechowało podobne działanie do działania warfaryny u pacjentów niestosujących wcześniej VKA (HR 0,92, 95\% Cl 0,73-1,15), ale słabsze w grupie badanych stosujących już tę terapię (HR 1,31, 95\% Cl 1,08-1,60; $p=0,019)$. Ryzyko poważnych krwawień było znacząco obniżone w przypadku obu dawek edoksabanu niezależnie od wcześniejszego stosowania VKA [4].

W drugiej z ocenianych podgrup tego badania określano wpływ amiodaronu (który w wyniku hamowania glikoproteiny P zwiększa stężenie edoksabanu w osoczu) na skuteczność i bezpieczeństwo terapii badanym lekiem. W porównaniu z warfaryną wystąpienie pierwszorzędowego punktu końcowego w postaci udaru lub zatorowości systemowej było zdecydowanie rzadsze w grupie pacjentów przyjmujących jednocześnie edoksaban w dawce 30 mg i amiodaron niż u tych, którzy nie przyjmowali dodatkowo amiodaronu. Z kolei amiodaron nie wykazywał żadnego wpływu na działanie podczas jednoczesnego stosowania z większymi dawkami edoksabanu [5].

Podsumowując wyniki tego badania, edoksaban wydaje się lekiem bezpiecznym, skutecznym oraz wykazującym mniej działań niepożądanych w porównaniu z warfaryną w profilaktyce udaru u chorych z NVAF. Zarówno dawka 60 mg, jak i 30 mg stosowane raz/dobę okazały się skuteczne w prewencji powikłań zakrzepowo-zatorowych oraz bezpieczniejsze niż warfaryna pod względem poważnych krwawień u pacjentów z NVAF $[2,3]$.

\section{Edoksaban u pacjentów z NVAF poddawanych kardiowersji elektrycznej}

W niedawno zakończonym randomizowanym, prospektywnym badaniu III fazy ENSURE-AF (The EdoxabaN vs. warfarin in subjectS UndeRgoing cardiovErsion of Atrial Fibrillation) oceniano skuteczność i bezpieczeństwo stosowania edoksabanu w porównaniu z enoksaparyną/warfaryną u 2199 pacjentów z NVAF poddawanych kardiowersji elektrycznej. W badanej grupie brano pod uwage wynik echokardiografii przezprzełykowej (TEE, transthoracic echocardiography), wcześniejsze przyjmowanie leków przeciwzakrzepowych oraz zastosowaną dawkę edoksabanu $(60 \mathrm{mg}$ lub $30 \mathrm{mg}$ $\mathrm{raz} / \mathrm{d}$.). Dawkę edoksabanu zmniejszono u pacjentów z niewydolnością nerek (klirens kreatyniny 15-50 ml/min), małą masą ciała $(\leq 60 \mathrm{~kg}$ ) lub przyjmujących inhibitor glikoproteiny $\mathrm{P}$ (z wyjątkiem amiodaronu). Dawkę warfaryny dostosowywano tak, aby utrzymać wartości INR w przedziale terapeutycznym. Obserwacja trwała 58 dni po kardiowersji elektrycznej $[6,7]$.

Do badania włączono pełnoletnich pacjentów z udokumentowanym AF trwającym co najmniej 48 godzin, ale krótszym niż 12 miesięcy (a w przypadku braku wyników badań potwierdzających objawowe AF, jeśli istniało uzasadnione przekonanie o takim czasie trwania arytmii), którzy byli zakwalifikowani do kardiowersji elektrycznej i terapii przeciwzakrzepowej. Włączono do badania zarówno tych pacjentów, którzy wcześniej stosowali leczenie przeciwzakrzepowe i/lub przeciwpłytkowe, jak i tych, którzy uprzednio nie przyjmowali takiej terapii. Pacjenci byli losowo przydzielani do dwóch grup - w pierwszej grupie przed zabiegiem kardiowersji elektrycznej wykonywano badanie TEE oraz stosowano leczenie przeciwkrzepliwe, w drugiej grupie zaś pacjentów przygotowywano do zabiegu za pomocą leczenia przeciwkrzepliwego. W obrębie tych grup badanych poddawano randomizacji do dwóch podgrup różniących się stosowanym leczeniem - enoksaparyna/ /warfaryną w porównaniu z edoksabanem. W grupie chorych przygotowywanych za pomocą TEE wydzielono tych, którzy nie przyjmowali wcześniej VKA lub stosowali takie leczenie, ale nie udało się uzyskać u nich terapeutycznych wartości INR - otrzymywali oni w dniu randomizacji 1 dawkę enoksaparyny i warfaryny, aż do osiągnięcia wartości terapeutycznych INR ( $\geq 2)$, następnie kontynuowano terapię samą warfaryną. Pacjenci, którzy w chwili randomizacji przyjmowali leczenie przeciwzakrzepowe oraz osiągnęli prawidłowe wartości INR, byli leczeni od dnia randomizacji jedynie warfaryną, której dawki dostosowywano tak, aby utrzymać terapeutyczne wartości INR $(2,0-3,0)$. Pacjenci przydzieleni do przyjmowania edoksabanu rozpoczynali 


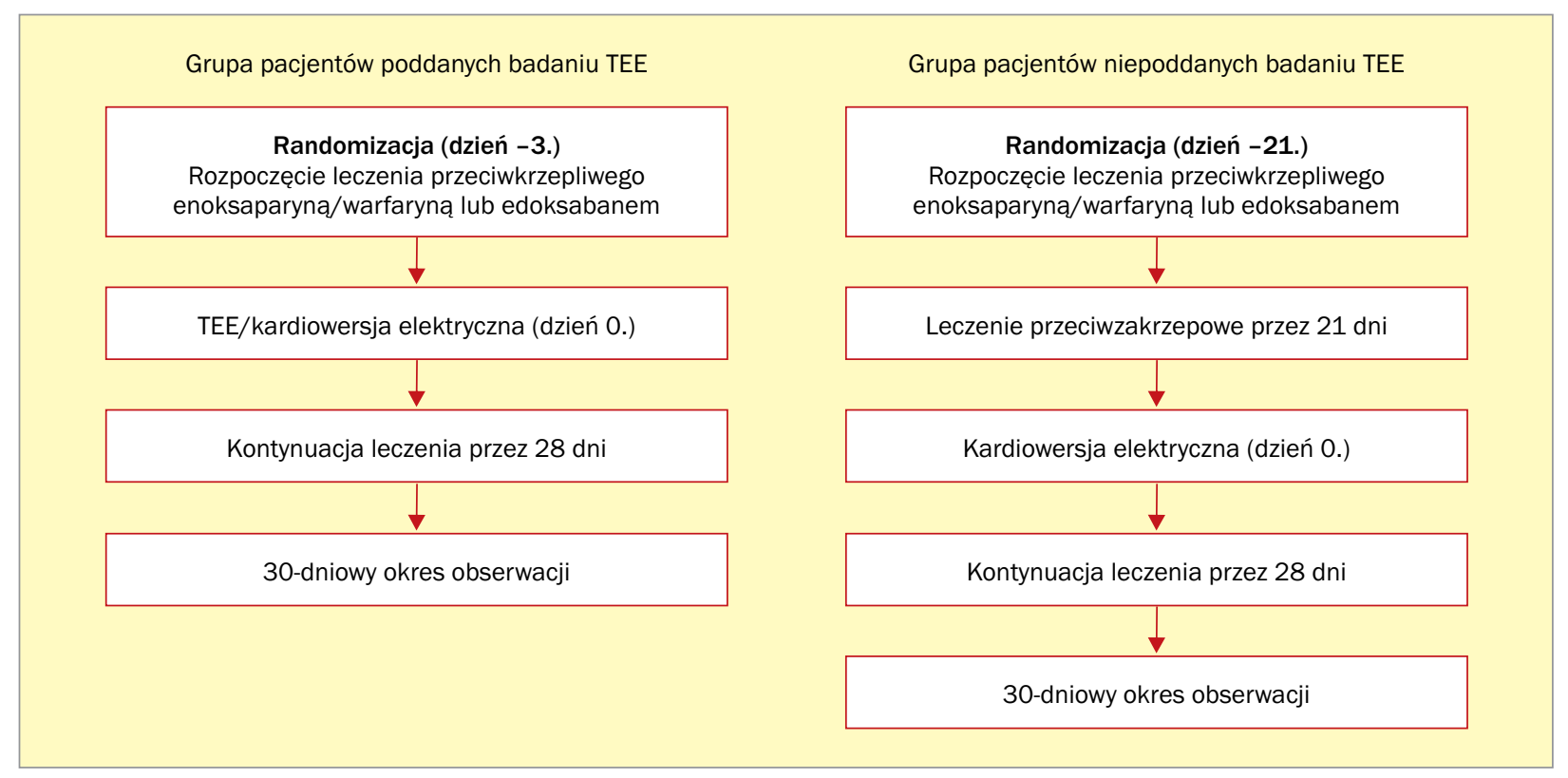

Rycina 1. Schemat protokołu badania ENSURE-AF (The EdoxabaN vs. warfarin in subjectS UndeRgoing cardiovErsion of Atrial Fibrillation) (opracowano na podstawie [6, 7]); TEE (transthoracic echocardiography) - echokardiografia przezprzełykowa

leczenie tym lekiem w dniu randomizacji i kontynyuowali je po zabiegu. Bez względu na stosowany lek, jeżeli nie uwidoczniono skrzepliny w przedsionku w badaniu TEE, pacjenci byli poddawani kardiowersji elektrycznej, ale zabieg ten musiał być wykonany maksymalnie w ciągu 3 dni od randomizacji. Następnie przez 28 dni kontynuowano leczenie danym lekiem. W przypadku wykrycia skrzepliny w badaniu obrazowym pacjenci nie byli poddawani kardiowersji, a po 28 dniach leczenia ponownie kontrolowano ich za pomocą badania echokardiograficznego. W grupie pacjentów nieprzygotowywanych za pomocą TEE do kardiowersji ustalono takie same zasady włączania leczenia za pomoca enoksaparyny i warfaryny lub samej warfaryny jak w grupie poprzedniej. Różnica polegała na okresie leczenia - przez 21 dni prowadzono leczenie edoksabanem bądź enoksaparyna/warfaryną, po czym wykonywano kardiowersję elektryczną (z maksymalnym opóźnieniem do 3 dni). Następnie kontynuowano leczenie danym lekiem przez 28 dni. Po zakończonym leczeniu, zarówno w grupie przygotowywanej do zabiegu za pomocą TEE, jak i w grupie, w której tego badania nie wykonano, wszystkich pacjentów poddawano 30-dniowej obserwacji [7]. Schemat protokołu badania przedstawiono na rycinie 1.

Głównym kryterium oceny skuteczności było wystąpienie punktu końcowego złożonego z udaru, epizodu zatorowości systemowej, zawału serca, zgonu z przyczyn sercowo-naczyniowych. W badaniu zaobserwowano porównywalną częstość występowania punktu końcowego w grupie leczonej edoksabanem i w grupie leczonej enoksaparyna/warfaryną (0,5\% v. 1\%). Najważniejszą różnicę stanowiło wystąpienie zgonu z przyczyn sercowo-naczyniowych
(1 zdarzenie w grupie leczonej edoksabanem, $5 \mathrm{w}$ grupie leczonej enoksaparyna/warfaryną; 0,1\% v. 0,5\%). W zakresie bezpieczeństwa za punkt końcowy uznano wystąpienie poważnego oraz istotnego klinicznie, innego niż poważne krwawienia u pacjentów, którzy otrzymali co najmniej 1 dawkę badanego leku. Nie stwierdzono istotnych statystycznie różnic w zakresie częstości występowania tych powikłań; $1,5 \%$ odnotowano w grupie przyjmującej edoksaban i $1 \%$ w grupie przyjmującej warfarynę, natomiast częstość poważnych krwawień była niższa w grupie leczonej edoksabanem (odpowiednio 0,3\% v. 0,5\%) [6].

Podsumowując, częstość występowania punktów końcowych w obu grupach była niewielka i porównywalna, niezależnie od sposobu przygotowania pacjenta do kardiowersji elektrycznej oraz wcześniejszego przyjmowania leków przeciwzakrzepowych. Edoksaban okazał się skuteczna i bezpieczną alternatywą dla leczenia enoksaparyną/ /warfaryną u pacjentów z NVAF poddawanych kardiowersji elektrycznej [6].

\section{Edoksaban w leczeniu żylnej choroby zakrzepowo-zatorowej}

Badanie Hokusai-VTE (Edoxaban versus warfarin for the treatment of symptomatic venous thromboembolism) było randomizowanym, przeprowadzonym metodą podwójnie ślepej próby badaniem klinicznym, które przeprowadzono w celu oceny skuteczności edoksabanu w leczeniu i profilaktyce nawrotów zakrzepicy żył głębokich oraz zatorowości płucnej. Do badania poddano randomizacji 8292 pacjentów w wieku 18 lat i starszych, u których 


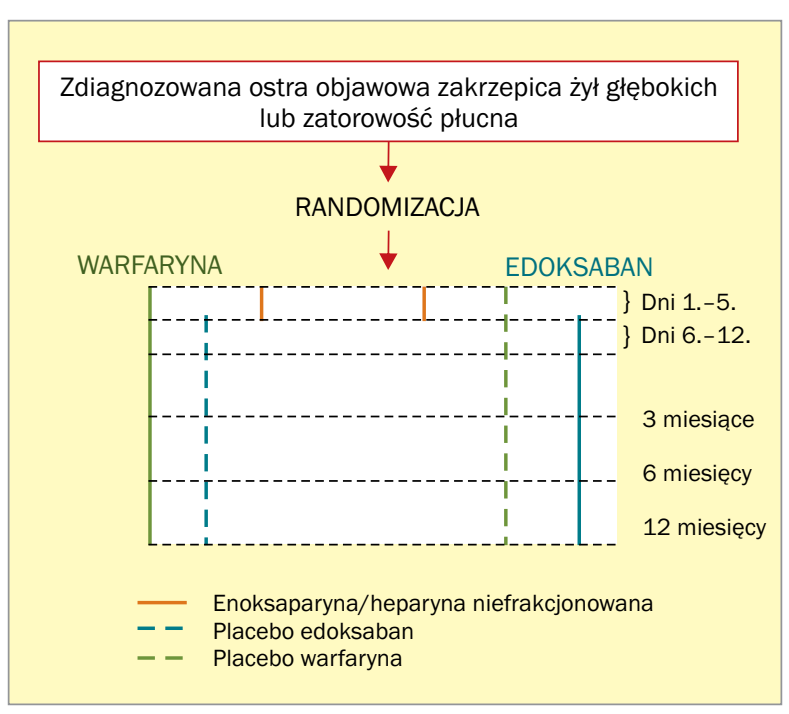

Rycina 2. Schemat protokołu badania Hokusai-VTE (Edoxaban versus warfarin for the treatment of symptomatic venous thromboembolism) (opracowano na podstawie [8])

zdiagnozowano ostrą, objawową zakrzepicę żył głębokich (w tym żyły podkolanowej, udowej lub żył biodrowych) bądź ostrą, objawową zatorowość płucną (z zakrzepicą żył głębokich lub bez niej). Leczenie edoksabanem lub warfaryną stosowano metodą podwójnie ślepej próby kontrolowanej placebo. Wszyscy pacjenci początkowo otrzymywali heparynę (enoksaparynę lub heparynę niefrakcjonowaną) - przez co najmniej 5 dni. Edoksaban w dawce $60 \mathrm{mg}$ $\mathrm{raz} /$ dobę lub w dawce $30 \mathrm{mg} \mathrm{raz/dobę} \mathrm{(pacjenci} \mathrm{z} \mathrm{masa}$ ciała < $60 \mathrm{~kg}$, umiarkowaną lub ciężką niewydolnością nerek albo przyjmujący jednocześnie leki będące silnymi inhibitorami P-gp) podawano po zakończeniu wstępnego leczenia heparyną. W grupie leczonej warfaryną pacjenci otrzymali lek równocześnie $z$ heparyną, w dawkach pozwalających na uzyskanie docelowej wartości INR między 2,0 a 3,0. Okres leczenia wynosił 3-12 miesięcy, zależnie od cech klinicznych pacjenta określonych przez lekarza prowadzącego i preferencji badanego (ryc. 2) [2, 8].

Pierwszorzędowy punkt końcowy oceny skuteczności w badaniu stanowił nawrót objawowej żylnej choroby zakrzepowo-zatorowej (VTE, venous thrombembolism), zdefiniowany jako złożenie nawracającej, objawowej zakrzepicy żył głębokich, niezakończonej zgonem objawowej zatorowości płucnej oraz śmiertelnej zatorowości płucnej podczas 12-miesięcznego okresu badania. Drugorzędowy punkt końcowy obejmował pierwszorzędowy punkt końcowy oraz zgony z przyczyn sercowo-naczyniowych i zgony z jakiejkolwiek przyczyny. W zakresie bezpieczeństwa terapii za najważniejszy punkt końcowy uznano wystąpienie istotnego klinicznie krwawienia (ciężkie krwawienie lub krwawienie istotne klinicznie, inne niż poważne) [8].
Wyniki badania dostarczyły następujących informacji: zakrzepice żył głębokich rozpoznano u 4921 pacjentów, u 3319 zaś - epizody zatorowości płucnej. Wśród pacjentów otrzymujących warfarynę mediana czasu, w którym stężenie leku znajdowało się w przedziale wartości terapeutycznych, wynosiła $63,5 \%$. Nawrót zakrzepicy żylnej w trakcie badania zaobserwowano u 130 pacjentów przyjmujących edoksaban $(3,2 \%)$ oraz 146 pacjentów w grupie leczonej warfaryna (3,5\%) (HR 0,89, 95\% Cl 0,70-1,13; p < 0,001). Wśród badanych zakwalifikowanych do otrzymywania $30 \mathrm{mg}$ edoksabanu pierwszorzędowy punkt końcowy obserwowano u 22 z 733 chorych (3,0\%) w porównaniu z 30 z 719 (4,2\%) otrzymujących warfarynę (HR 0,73, 95\% $\mathrm{Cl} 0,42-1,26)$. Spośród 938 chorych z zatorem tętnicy płucnej i udowodnioną dysfunkcją prawej komory (ocenianą na podstawie stężenia N-końcowego propeptydu natriuretycznego typu B [NT-proBNP, N-terminal prohormone B-type natriuretic peptide] $\geq 500 \mathrm{pg} / \mathrm{ml}$ ) nawrót zakrzepicy żylnej wystapił u 15 z 454 pacjentów (3,3\%) w grupie leczonej edoksabanem i u 30 z $484(6,2 \%)$ przyjmujących warfaryne (HR $0,52,95 \% \mathrm{Cl} 0,28-0,98)$. Klinicznie istotne krwawienia wystąpiły u 349 pacjentów z 4118 osób (8,5\%) otrzymujących edoksaban oraz u 423 badanych z $4122(10,3 \%)$ w grupie leczonej warfaryną ( $\mathrm{HR} \mathrm{0,81,95 \%} \mathrm{Cl} 0,71-0,94$; $p=0,004)$. W grupie pacjentów przyjmujących edoksaban $w$ dawce $30 \mathrm{mg} \mathrm{raz} /$ dobę klinicznie istotne krwawienia występowały u 7,9\% (58 z 733) osób przyjmujących ten lek oraz u 12,8\% (92 z 719) otrzymujących warfarynę (HR $0,62,95 \% \mathrm{Cl} 0,44-0,86)$. Częstość występowania innych działań niepożądanych była podobna w obu grupach [8].

W przytoczonym badaniu edoksaban przyjmowany raz/ /dobę po wstępnym leczeniu heparyną okazał się równie skuteczną metodą leczenia jak standardowa terapia warfaryną. Z powodu wywoływania mniejszej liczby istotnych klinicznie krwawień edoksaban wydaje się atrakcyjną alternatywą dla warfaryny w leczeniu i zapobieganiu nawrotom VTE [8].

\section{Edoksaban w prewencji zakrzepicy żylnej u pacjentów po operacjach ortopedycznych}

W japońskim randomizowanym, przeprowadzonym metodą podwójnie ślepej próby, badaniu klinicznym III fazy STARS J-V (Studying Thrombosis After Replacement Surgery J-V) wykazano bezpieczeństwo i skuteczność edoksabanu w profilaktyce VTE po zabiegach ortopedycznych. W badaniu pacjentów po planowej, jednostronnej endoprotezoplastyce stawu biodrowego poddano randomizacji do grup otrzymujących edoksaban $30 \mathrm{mg}$ raz/dobę (liczba pacjentów: 307) oraz enoksaparynę w dawce 2000 jm. 2 razy/dobę (liczba pacjentów 303) przez 11-14 dni. Pierwszorzędowym punktem końcowym był epizod VTE. W zakresie bezpieczeństwa badanego leku punkt końcowy stanowiło 
wystąpienie poważnego lub klinicznie istotnego (innego niż poważne) krwawienia [2, 9]. Odsetek epizodów VTE wynosił $2,4 \%$ w grupie otrzymującej edoksaban (6/255) i 6,9\% w grupie leczonej enoksaparyną (17/248). Nie zaobserwowano istotnej różnicy w zakresie częstości występowania poważnych krwawień lub klinicznie istotnych krwawień (innych niż poważne) podczas leczenia edoksabanem (2,6\%) w porównaniu z enoksaparyną (3,7\%) [9].

Podsumowując, w badaniu wykazano skuteczność terapii doustnym edoksabanem stosowanym raz/dobę w porównaniu z podskórnie podawaną 2 razy/dobę enoksaparyną w profilaktyce VTE u pacjentów po endoprotezoplastyce stawu biodrowego $[2,9]$.

\section{Pozycjonowanie edoksabanu u chorych z migotaniem przedsionków}

Metaanalizy badań klinicznych dotyczących NOAC wykazały korzystny profil bezpieczeństwa tych leków oraz redukcję ryzyka udaru i krwotoku śródczaszkowego oraz śmiertelności u pacjentów z NVAF; NOAC charakteryzują się podobnym ryzykiem poważnych krwawień, co warfaryna [10]. Wśród tych leków znajduje się edoksaban - skuteczny i bezpieczny antykoagulant będący atrakcyjną alternatywą dla tradycyjnego leczenia przeciwzakrzepowego prowadzonego za pomocą VKA w prewencji udaru mózgu u pacjentów z NVAF. W badaniu ENGAGE AF stwierdzono znacznie mniejszą liczbę incydentów niedokrwiennych u pacjentów leczonych amiodaronem i edoksabanem w porównaniu z warfaryną. Jednak dawka edoksabanu powinna zostać zmniejszona, gdy są stosowane leki antyarytmiczne, takie jak werapamil lub dronedaron [11]. W porównaniu z terapią warfaryną edoksaban w dawce $60 \mathrm{mg} \mathrm{raz/dobę} \mathrm{zwiększał}$ ryzyko krwawień do przewodu pokarmowego u pacjentów z AF, dlatego też zaleca się stosowanie zmniejszonej dawki u chorych obciążonych wysokim ryzykiem takich krwawień. Redukcja dawki edoksabanu jest także konieczna u chorych z AF oraz ze współistniejącą przewlekłą chorobą nerek (klirens kreatyniny 30-49 $\mathrm{ml} / \mathrm{min}$ ), a u chorych dializowanych lek ten nie powinien być stosowany. Na- tomiast wiek pacjenta nie jest wskazaniem do redukcji dawki edoksabanu [12]. W przypadku rozpoczęcia terapii przeciwzakrzepowej w prewencji udaru mózgu u pacjentów z AF edoksaban stanowi korzystny wybór u chorych ze współistniejącą przewlekłą chorobą nerek (w zmniejszonej dawce), dyspepsją lub objawami żołądkowo-jelitowymi, obciążonych wysokim ryzykiem krwawień (wynik w skali HAS-BLED $\geq 3$ pkt.) oraz u pacjentów preferujących stosowanie leku raz dziennie [13].

\section{Podsumowanie}

Edoksaban - dobrze tolerowany bezpośredni inhibitor czynnika Xa, stosowany raz/dobę - to lek, który wykazuje równoważną skuteczność w porównaniu ze standardowymi schematami leczenia przeciwkrzepliwego zarówno w profilaktyce udaru mózgu u pacjentów z NVAF, jak i w leczeniu oraz prewencji nawrotów VTE, zachowując przy tym korzystny profil bezpieczeństwa. Znaczna redukcja ryzyka udaru krwotocznego mózgu, krwawienia śródczaszkowego i śmiertelności z przyczyn sercowo-naczyniowych sprawia, że lek ten wydaje się atrakcyjną alternatywą dla tradycyjnego leczenia VKA w profilaktyce udaru mózgu u pacjentów z NVAF.

Nie jest obecnie dostępne swoiste antidotum dla edoksabanu. Jednak w przeprowadzonych dotychczas badaniach wykazano, że leki przeciwkrwotoczne, takie jak koncentrat czynników zespołu protrombiny (PCC, prothrombin complex concentrate), zespół czynników krzepnięcia przeciw inhibitorowi czynnika VIII (FEIBA, factor eight inhibitor bypassing activity) oraz aktywny rekombinowany ludzki czynnik VII (rhFVIla, activated recombinant human factor VII), mogą ograniczyć zmiany wywoływane przez edoksaban w czasie protrombinowym w sposób zależny od stężenia. Ponadto trwają intensywne badania kliniczne nad antidotum dla inhibitorów czynnika Xa (andexanet alfa) [2].

\section{Konflikt interesów}

Autorzy nie zgłaszają konfliktu interesów.

\section{Abstract}

Non-vitamin K oral antagonist anticoagulants (NOAC) demonstrated efficiency and safety in several clinical trials. These drugs are a promising alternative to standard anticoagulation therapy. One of them is edoxaban - highly selective, reversible and direct inhibitor of factor Xa. It can be used in states that require anticoagulant prophylaxis and treatment, such as prevention of stroke and systemic embolism in patients with nonvalvular atrial fibrillation and treatment of deep vein thrombosis and pulmonary embolism. The following article presents an analysis of clinical trials conducted to evaluate safety and efficiency of edoxaban.

Key words: non-vitamin K antagonist oral anticoagulants, edoxaban, warfarin, atrial fibrillation, venous thromboembolism

Folia Cardiologica 2017; 12, 1: 61-67 


\section{Piśmiennictwo}

1. Ruff CT, Giugliano RP, Antman EM, et al. Evaluation of the novel factor Xa inhibitor edoxaban compared with warfarin in patients with atrial fibrillation: design and rationale for the Effective aNticoaGulation with factor XA next GEneration in Atrial Fibrillation-Thrombolysis In Myocardial Infarction study 48 (ENGAGE AF-TIMI 48). Am Heart J. 2010; 160(4): 635-641, doi: 10.1016/j.ahj.2010.06.042, indexed in Pubmed: 20934556.

2. Bounameaux H, Camm AJ. Edoxaban: an update on the new oral direct factor Xa inhibitor. Drugs. 2014; 74(11): 1209-1231, doi: 10.1007/ /s40265-014-0261-1, indexed in Pubmed: 25034361.

3. Link MS, Giugliano RP, Ruff CT, et al. ENGAGE AF-TIMI 48 Investigators, ENGAGE AF-TIMI 48 Investigators, ENGAGE AF-TIMI 48 Investigators, ENGAGE AF-TIMI 48 Investigators. Edoxaban versus warfarin in patients with atrial fibrillation. N Engl J Med. 2013; 369(22): 2093-2104, doi: 10.1056/NEJMoa1310907, indexed in Pubmed: 24251359.

4. O'Donoghue ML, Ruff CT, Giugliano RP, et al. Edoxaban vs. warfarin in vitamin $\mathrm{K}$ antagonist experienced and naive patients with atrial fibrillation. Eur Heart J. 2015; 36(23): 1470-1477, doi: 10.1093/eurheartj/ /ehv014, indexed in Pubmed: 25687352.

5. Steffel J, Giugliano RP, Braunwald E, et al. Edoxaban vs. warfarin in patients with atrial fibrillation on amiodarone: a subgroup analysis of the ENGAGE AF-TIMI 48 trial. Eur Heart J. 2015; 36(33): 2239-2245, doi: 10.1093/eurheartj/ehv201, indexed in Pubmed: 25971288.

6. Goette A, Merino JL, Ezekowitz MD, et al. ENSURE-AF investigators. Edoxaban versus enoxaparin-warfarin in patients undergoing cardioversion of atrial fibrillation (ENSURE-AF): a randomised, open-label, phase 3b trial. Lancet. 2016; 388(10055): 1995-2003, doi: 10.1016/ /S0140-6736(16)31474-X, indexed in Pubmed: 27590218.

7. Lip GYH, Merino J, Ezekowitz M, et al. A prospective evaluation of edoxaban compared to warfarin in subjects undergoing cardioversion of atrial fibrillation: The EdoxabaN vs. warfarin in subjectS UndeRgoing cardiovErsion of Atrial Fibrillation (ENSURE-AF) study. Am Heart J. 2015; 169(5): 597-604.e5, doi: 10.1016/j.ahj.2015.02.009, indexed in Pubmed: 25965706.

8. Büller HR, Décousus H, Grosso MA, et al. Hokusai-VTE Investigators. Edoxaban versus warfarin for the treatment of symptomatic venous thromboembolism. N Engl J Med. 2013; 369(15): 1406-1415, doi: 10.1056/NEJMoa1306638, indexed in Pubmed: 23991658.

9. Fuji T, Fujita S, Kawai Y, et al. Efficacy and safety of edoxaban versus enoxaparin for the prevention of venous thromboembolism following total hip arthroplasty: STARS J-V. Thromb J. 2015; 13: 27 , doi: 10.1186/s12959-015-0057-x, indexed in Pubmed: 26269694.

10. Ruff CT, Giugliano RP, Braunwald E, et al. Comparison of the efficacy and safety of new oral anticoagulants with warfarin in patients with atrial fibrillation: a meta-analysis of randomised trials. Lancet. 2014; 383(9921): 955-962, doi: 10.1016/S0140-6736(13)62343-0, indexed in Pubmed: 24315724.

11. Diener HC, Aisenberg J, Ansell J, et al. Choosing a particular oral anticoagulant and dose for stroke prevention in individual patients with non-valvular atrial fibrillation: part 1. Eur Heart J. 2016 [Epub ahead of print], doi: 10.1093/eurheartj/ehv643, indexed in Pubmed: 26848149.

12. Diener HC, Aisenberg J, Ansell J, et al. Choosing a particular oral anticoagulant and dose for stroke prevention in individual patients with non-valvular atrial fibrillation: part 2. Eur Heart J. 2016 [Epub ahead of print], doi: 10.1093/eurheartj/ehw069, indexed in Pubmed: 26848150.

13. Lip GYH, Lane DA. Matching the NOAC to the Patient: Remember the Modifiable Bleeding Risk Factors. J Am Coll Cardiol. 2015; 66(21): 2282-2284, doi: 10.1016/j.jacc.2015.07.086, indexed in Pubmed: 26610875. 